Article

\title{
Perceptions of parents of under-5-year-old children with pneumonia on the effects of tobacco smoke: A phenomenology study in Manggarai, Eastern Indonesia
}

\author{
Paskaliana Hilpriska Danal, ${ }^{1}$ Nani Nurhaeni, ${ }^{2}$ Nur Agustini ${ }^{2}$ \\ ${ }^{1}$ Faculty of Health and Agricultural Science, Universitas Katolik Santu Paulus Ruteng, Flores; ${ }^{2}$ Department of \\ Pediatric Nursing, Faculty of Nursing, Universitas Indonesia, Depok, West Java, Indonesia
}

\begin{abstract}
Background: In Eastern Indonesia, the incidence of pneumonia in under-5-year-old children is mostly predicted by environmental factors, such as exposure to household smoke and tobacco smoke. Sociocultural ideas shape the perception of parents on the effect of tobacco smoke thus influence their behaviour on reducing the smoke exposure on their child. The present study aimed to explore the perceptions of parents of under-5-year-old children with pneumonia about the effects of exposure to tobacco smoke.

Design and Methods: This qualitative study was conducted using a phenomenological approach. The study participants were 11 parents of under-5-year-old children with pneumonia in Manggarai, Eastern Indonesia. The data were collected through in-depth interviews and then analyzed using the Colaizzi method.

Results: The themes identified in the present study were i) "I know the risk of smoke, I can't help it" various perceptions on tobacco smoke effect; ii) tobacco causes shortness of breath on under-5-year-old children; and iii) tobacco smoke taking tolls on family's health and economy.

Conclusions: The findings revealed that parent view tobacco smoke endanger children's health and hamper the socio-economic well-being of the family. It is necessary to improve parent's awareness about the effects of tobacco smoke through effective nursing communication that suits the family's needs and conditions.
\end{abstract}

\section{Introduction}

Globally, two under-5-year-old children die every minute due to pneumonia; $99 \%$ of these children belong to developing countries. ${ }^{1}$ Pneumonia is the major cause of death from infectious diseases $(15 \%)$ in children worldwide makes it the global priority of intervention. ${ }^{2}$. The prevalence of pneumonia in Indonesia increased from $1.6 \%$ in 2013 to $2 \%$ in $2018 .{ }^{3}$ Interventions in Indonesia focus on controlling the incidence of pneumonia by increasing the case detection rate to $80 \% .{ }^{4}$ To reach this target, several health programs, such as the Integrated Management of Childhood Illness Program (Manajemen Terpadu Balita Sakit, MTBS) and Acute Airway Infection Control Program (Pengendalian Penyakit Infeksi Saluran Pernapasan Akut, P2
ISPA), have been launched by the Ministry of Health; public health workers and pediatric nurses are at the front line in these programs. ${ }^{4,5}$ Pneumonia is often triggered by several factors, such as exposure to household smoke, crowding, and parental smoking. ${ }^{2}$ Acute respiratory infection in children, particularly in Eastern Indonesia, is caused by several environmental risk factors, such as prenatal exposure to smoke and household pollution due to solid fuel use, in addition to mother/caregiver experiences and non-exclusive breastfeeding. ${ }^{6}$ Moreover, under-5-year-old children who have a smoker parent or who live with a smoker have a higher chance of inhaling more than 40 carcinogens from tobacco smoke. ${ }^{7}$ Approximately $78 \%$ of women and children in 31 countries, including Indonesia, are exposed to tobacco smoke at home, as revealed by their hair nicotine concentration. The hair nicotine concentration is twofold higher in under-5-year-old children. ${ }^{8}$

Tobacco is one of the main substances used in every traditional ritual in Manggarai, in addition to alcoholic beverages, betel leaves, and areca nuts. ${ }^{9,10}$ Smoking is also considered a norm among men in Manggarai, ${ }^{11}$ as a result of which smoking behavior is common among these men. Previous research has revealed that the perceptions of parents about the effects of tobacco smoke are related to the parents' ethnicity and smoking behavior. ${ }^{12}$ It is also important to notice that the harmful effects of tobacco smoke are not only caused by direct exposure by smoke inhalation but also caused by indirect exposure, e.g., by inhaling the residue and by being in contact with a smoker; these effects may be very harmful to children. ${ }^{13}$ Thus, in order to modify smoking behavior, parents need to be convinced that exposure to tobacco smoke includes indirect exposure as well.

Parent's perception and understanding on the effect of tobacco smoke is an important first step of stopping tobacco exposure to the children. The previous research highlighted that the majority of parents especially the smoker parents acknowledging the danger of tobacco smoke but do not belief that tobacco smoke directly causes illness to their children. ${ }^{7}$ This is in line with other study that states parents perception on their child's illness severity influence their motivation to stop smoking. ${ }^{14}$ While in Manggarai itself, tobacco and smoking behaviour become the significant part of culture and tradition, ${ }^{11}$ addressing parent's perception towards its effect on their child health is a vital part to protect their children of the harm in the social and cultural setting, where tobacco smoke is evident. To stop the exposure of under-5-year-old children with

Significance for public health

As this study identifies parents' perception on the effect of tobacco smoke, it is expected to underlie and shape the smoking prevention intervention in the specific culturally-bound smoking behaviour such as in Manggarai, Eastern Indonesia. 
pneumonia to tobacco smoke, the perceptions of parents, especially in a culture where smoking behavior is common (e.g., in Manggarai), need to be understood first and then be modified. Understanding the perceptions of parents is significant because in order to implement a proper nursing intervention for under-5-yearold children with pneumonia in Manggarai, nurses have to explain culturally sensitive and relevant care to the parents. The present study aimed to explore the perceptions of parents of under-5-yearold children with pneumonia about the effects of tobacco smoke in Manggarai, East Nusa Tenggara, Eastern Indonesia.

\section{Design and Methods}

The present qualitative study used a descriptive phenomenological approach to explore the perceptions of parents of under-5-year-old children with pneumonia about the effects of tobacco smoke. Phenomenology approach was used so the researcher able to explore the participant's life experiences comprehensively, detailed flexible yet consistent and coherent with participant's point of view. ${ }^{15}$ Purposive sampling was used so that the researcher could focus on the unique characteristics of parents of children with pneumonia in order to answer the research question. The study participants were parents of under-5-year-old children who were currently or ever hospitalized due to pneumonia. Parents of under-5-year-old children whose pneumonia had worsened and who were currently receiving intensive care were excluded from the study. The data collected through the in-depth interviews and then analyzed using the Colaizzi method. Interviews were performed from February to March 2020. Data achieve the saturation on the eleventh participant; therefore, the data collection were stopped. In order to maintain data rigour and trustworthiness, researcher apply member checking of the data analysis draft to the participants and conduct data triangulation with the research supervisor.

\section{Results}

The participants were recruited by referring to the medical records at Dr. Ben Mboi Manggarai Regency Hospital. Data were collected from March to June 2020. In total, 11 participants were included in the present study. The participants' demographics are provided in Table 1. Three main themes were identified in the present study: i) "I know the risk of smoke, I can't help it" various perceptions on tobacco smoke effect; ii) tobacco causes shortness of breath on under-5-year-old children; and iii) tobacco smoke taking tolls on family's health and economy.

\section{Theme 1. "I know the risk of smoke, I can't help it" - various perceptions on tobacco smoke effect}

\section{Sub-theme 1. Dangerous effects of tobacco smoke}

The participants stated that tobacco smoke had a lot of disadvantages and was dangerous to children and others. Their thoughts were as follows:

"Tobacco smoke... even from afar... the smell is really disturbing.” (P5)

"So, to me, uh, smoking could be harmful to others. So, I think that people who smoke, especially in public places, don't value other people's lives." (P6)

Some of the participants were aware of the danger of tobacco and tobacco smoke. A participant even further describing smoking behaviour is an unacceptable behaviour to be conducted in the public areas.

\section{Sub-theme 2. Positive views on tobacco smoke}

Some participants viewed smoking behavior positively. They thought of the positive effects of smoking behavior, e.g., facilitating social interaction with other people. Some parents also thought that smoking would help them to focus while working.

"It would be unenthusiastic for us to not smoke while working or farming... Indeed, that (smoking) helps us stay awake during traditional funeral rites." (P1)

"Sometimes, if we do not smoke, it seems like we are not trying to be close and are unfriendly." (P8)

Some participants perceive smoking behaviour as an important part of social and cultural gathering. Tobacco also perceived as the important traditional rite's item.

Table 1. Participants' demographics.

\begin{tabular}{|c|c|c|c|c|c|c|c|c|c|c|}
\hline \multirow[b]{2}{*}{ Code } & \multirow[b]{2}{*}{ Sex } & \multirow[b]{2}{*}{$\begin{array}{l}\text { Age } \\
\text { (years) }\end{array}$} & \multicolumn{2}{|c|}{ Parents' profile } & \multirow[b]{2}{*}{ Occupation } & \multirow[b]{2}{*}{$\begin{array}{l}\text { Smoking } \\
\text { status }\end{array}$} & \multirow[b]{2}{*}{$\begin{array}{c}\text { Number of } \\
\text { in the household } \\
\text { smokers }\end{array}$} & \multicolumn{3}{|c|}{ Under-5-year-old children's profile } \\
\hline & & & Address & $\begin{array}{l}\text { Education } \\
\text { level }\end{array}$ & & & & Sex & $\begin{array}{l}\text { Age } \\
\text { (years) }\end{array}$ & $\begin{array}{l}\text { Hospitalization } \\
\text { status }\end{array}$ \\
\hline Pl & Male & 41 & Cibal sub-district & Elementary school & Farmer & Smoker & 1 & Female & 1 year 5 months & Hospitalized \\
\hline P2 & Female & 25 & Ruteng sub-district & Elementary school & Housewife & Non-smoker & 1 & Male & 2 years 10 months & Hospitalized \\
\hline P3 & Male & 33 & Satar Mese Barat sub-district & College & Nurse & Ex-smoker & None & Female & 5 months & Hospitalized \\
\hline P4 & Female & 32 & Satar Mese Barat sub-district & College & Teacher & Non-smoker & None & Female & 5 months & Hospitalized \\
\hline P5 & Female & 28 & Langke Rembong sub-district & College & Private sector employee & Non-smoker & 1 & Female & 7 months & Hospitalized 3 months ago \\
\hline P6 & Female & 25 & Langke Rembong sub-district & High school & Private sector employee & Non-smoker & 2 & Male & 1 year 7 months & Hospitalized 3 months ago \\
\hline P7 & Female & 31 & Wae Rili sub-district & High school & Housewife & Non-smoker & 1 & Male & 2 months & Hospitalized \\
\hline P8 & Male & 35 & Rahong Utara sub-district & College & Teacher & Smoker & 3 & Female & 1 year 2 months & Hospitalized \\
\hline P9 & Female & 33 & Satar Mese Barat sub-district & Elementary school & Farmer & Non-smoker & None & Male & 3 months & Hospitalized \\
\hline $\mathrm{P} 10$ & Male & 43 & Satar Mese Barat sub-district & Elementary school & Farmer & Non-smoker & None & Male & 3 months & Hospitalized \\
\hline P11 & Female & 22 & Satar Mese Barat sub-district & Middle school & Farmer & Non-smoker & 1 & Male & 2 years 6 months & Hospitalized \\
\hline
\end{tabular}


Sub-theme 3. Lack of awareness about the effects of tobacco smoke

The participants stated that they were less aware about the effects of tobacco smoke.

“...but sometimes, eh, we smokers never consider the dangers apparently." (P8)

"Even though I know the risk of smoke, I can't help it. I'm already a heavy smoker." (P3)

Participants also expressed their lack of awareness is because there were no knowledge of the direct effect of tobacco smoke.

\section{Theme 2. Tobacco causes shortness of breath on under-} 5-year-old children

\section{Sub-theme 1. Harmful effects of tobacco smoke on children's respiratory health}

The participants stated that there was a certain harmful effect of tobacco smoke on their children's health.

"Regarding under-5-year-old children, their immunity is still very weak. Sometimes, (they) experience shortness of breath or other symptoms." (P3)

"There, I knew that tobacco smoke is really dangerous. Tobacco smoke causes shortness of breath.” (P7)

Participants have clear knowledge on the effect of tobacco smoke for the children. Some participants acknowledge that the condition that their child suffer now is contributed by tobacco smoke exposure.

\section{Sub-theme 2. Other effects of tobacco smoke}

Apart from the harmful effects on the respiratory health of under-5-year-old children, the participants mentioned other effects of tobacco smoke.

"Tobacco is not good for children. They have to avoid (it). Moreover, when a child is sick, they have to avoid it around them. The problem is... my child is sick. Yes, surely, it would increase the illness... yeah." (P2)

"Besides, it can (cause) dizziness, ma'am. Yes, (it can make one) dizzy. ” (P7)

Some participants also stated the several additional symptom arose after their child were exposed to tobacco smoke. This syptoms included diziness and increase the severity of their illness.

\section{Sub-theme 3. Ignorance about the effects of tobacco smoke on children}

Several participants were ignorant about the harmful effects of tobacco smoke on their children.

"Eh, I do not really know that... maybe, there are a lot of effects. I don't know any... I don't know, ma'am." (P2)

"So, I myself don't know, eh, the effect of smoking. Is it just, eh, what's it called... caused by or a cause of an illness? I don't know. Then, eh, what's it called... I don't know whether the other illness is caused by smoke itself. However, I am unsure what is the cause of an illness." (P8)

Some participants stated that they dont have sufficient knowledge on the effect of tobacco smoke on their child's health. Some of them argue that there might be another causes of their child's illness rather than singling out tobacco smoke as the causeof the problem.

\section{Theme 3. Tobacco smoke taking tolls on family's health and economy}

\section{Sub-theme 1. Effects of tobacco smoke on the health of the family}

The participants mentioned the several effects of tobacco smoke on the health of the family and the resultant health symptoms.

"If a pregnant woman is exposed to tobacco smoke, it will affect the fetus. This means that it would be not good if tobacco smoke is mixed with oxygen and absorbed into the circulation. Moreover, a pregnant woman's body would help feed the fetus."

"Yeah, because... to be honest, if my husband's talking, he coughs. Every time after smoking, he would cough." (P7)

Participants above argue that tobacco smoke is not healthy for the family. Some stated from their experiences of health symptoms that follows after a family member smokes.

\section{Sub-theme 2. Other effects of smoking on the family}

The participants stated that tobacco smoking behavior not only harmed the health of the family but also affected the well-being of the family, e.g., by creating an emotional and economic burden.

"Yes, ma'am... because I've already known the misery and how bitter this illness can be. I have to fight against my husband and anyone else. Yes, (it's) really miserable because I can see it with my own eyes." (P7)

"...indeed, from the aspect of, yeah, economy it's really a loss... multiply the price. Yes. If (we) buy food with the money, it's probably really useful for everyone. However, using it to buy cigarettes, yeah, it's indeed selfish because it's only for the smoker." (P8)

Participant above shares their emotional experiences regarding to the effect of smoking behaviour on their family's health and economy. Smoking behaviour hampers family's financial states and affecting their basic daily needs fulfillment.

\section{Sub-theme 3. Effects of tobacco smoke on the family's social interaction}

The participants also mentioned that tobacco smoke affected their social interaction with their relatives and with others during traditional rites.

“...until now, if a traditional ceremony doesn't really require us to participate, we don't." (P5)

“...ma'am, that point too, because to ask a guest (to not smoke) is unfavorable. No, when they start smoking, they will continuously smoke, ma'am. They still smoke. Moreover, if it's combined with drinks, they will ignore our demand (to not smoke)." (P7) 
Participants above stated that as tobacco and smoking behaviour is an impotant item on Manggarai's culture, they felt that the burden of protecting the child's health is disturbing their social life. Some participants stated that they don't regularly participated in traditional ceremony because they know there would be alot of smoke and that their child's health is the priority.

\section{Discussion}

The results of the present study provide important information regarding the perceptions of parents of under-5-year-old children with pneumonia in Manggarai about the effects of tobacco smoke. The perception of parents is a significant predictor of children's health. ${ }^{13}$ The study participants had varied perceptions about the effects of tobacco smoke. While many participants thought that tobacco smoke is dangerous, some of them had positive views on smoking. The others stated that they lacked awareness about the effects of tobacco smoke. The diverse perceptions about smoking behavior are predicted by the different socio-demographic backgrounds and the parents' smoking status (smoker or non-smoker). ${ }^{16}$

Parents who view tobacco smoke as dangerous are likely to prevent the exposure of their children to tobacco smoke. It has been previously revealed that parents who think that smoking behavior is dangerous tend to impose smoke-free home rules and do not smoke around children. ${ }^{17,18}$ On the other hand, some parents stated that cigarettes help them in their jobs and to socialize with others. Smoking behavior has been identified to be an avoid kind of coping mechanism used to overcome stressors in a previous study. ${ }^{19}$ In this study, the stressor identified by the parent was work pressure and the need to interact. Thus, smoking behavior would hamper and decrease the efforts of preventing the exposure of children to tobacco smoke. ${ }^{12}$ In the present study, the positive views of the participants on smoking behavior by stating that smoking is acceptable and can be done anytime the smoker wishes. Thus, the risk of exposure of under-5-year-old children with pneumonia to tobacco smoke is increasing.

The participants expressed that they were less aware because of the lack of knowledge, their working status, and not experiencing the direct effects of tobacco smoke (e.g., children falling ill or getting hospitalized). A previous study proved that the perceptions and awareness of parents about the effects of passive smoking on children are influenced by the experience of health problems related to tobacco smoke ${ }^{17}$ In another study, parents were provided information on the level of exposure of their children, e.g., by measuring the levels of tobacco smoke exposure biomarkers in the children's hair or urine, in order to increase the parents' awareness. ${ }^{20}$ Future studies need to focus on this important issue in order to increase parents' awareness about the exposure of children to tobacco smoke.

The participants realized the harmful effects of tobacco smoke on the respiratory health of under-5-year-old children. This was reflected through their experiences of their children being prone to illnesses, e.g., shortness of breath and cough, after being exposed to tobacco smoke. The participants also stated that their children were susceptible to being unwell because of their weaker immune status. Exposure to smoke at home is known to be a predictive factor of the incidence of pneumonia in under-5-year-old children. ${ }^{21}$ In addition to respiratory disorders, exposure to tobacco smoke can cause chronic illnesses and other health symptoms, such as dizzi- ness. Furthermore, under-5-year-old children who are exposed to tobacco smoke at home, as revealed by their hair nicotine concentration, tend to have higher systolic blood pressure and lower highdensity lipoprotein (HDL) levels than those who are not exposed to tobacco smoke (no nicotine detected in the hair). Thus, children exposed to tobacco smoke have a higher risk of cardiovascular disease. $^{22}$

The participants also stated that tobacco smoke affects the health and well-being of the family. Exposure to tobacco smoke at home reduces the physical, social, economic, and psychological well-being of the entire family. ${ }^{23}$ Tobacco smoke also endangers the health of the family, including that of smokers, pregnant women, and passive smokers. Tobacco smoke poses a health danger to all age groups, particularly babies, children, elderly individuals, and pregnant women. It can have harmful effects, such as cancer, asthma attacks, and a lower birth weight ${ }^{24}$ The exposure of pregnant mothers to tobacco smoke is a predominant risk factor for lower airway infection or wheezing disease. ${ }^{25}$ The study participants were found to have sufficient knowledge about the effects of tobacco smoke on the health of the family.

Smoking behavior also hampers the financial condition. Some participants reported that they had to sacrifice their daily meal at times in order to provide cigarettes to their guest. Most cigarette consumers have a low socio-economic status and education level; thus, they have a higher risk of exposure. ${ }^{26}$ The reduction of smoking behavior in people with a low economic status can increase their short-term financial status by approximately 2.5 times. Moreover, in the long term effect, it can reduce the cost associated with chronic illnesses caused by smoking behavior. ${ }^{27}$ By reducing the exposure of children to tobacco smoke, families can avoid financial losses due to children's healthcare costs.

Smoking behavior is common during every traditional rite in Manggarai. In the Manggarai culture, cigarettes are served in every traditional ceremony, including weddings or engagements; this is known as seng wali tuak agu rongko (money for cigarettes and alcoholic beverages). ${ }^{28}$ This normalized smoking habit is known to be prevalent in people with a low education level and in smoker parents. ${ }^{29}$ Thus, health workers, particularly pediatric nurses, need to comprehensively provide health education not only to parents but also to the community. The participants expressed finding it difficult to participate in traditional ceremonies as they wanted to prevent their children from being exposed to tobacco smoke. The participants' social interaction with others, especially with smokers, was interrupted; they stopped the interaction and began to feel anxious when interacting with smokers. In order to be able to protect children, especially under-5-year-old children with pneumonia, pediatric nurses should consider parents' needs and devise the appropriate strategy.

A limitation of the present study is that the interview was mostly done in the hospital while child of the participants was hospitalized. In order to overcome these difficulties, the researcher decided the time and place of the interview according to each participant's comfort so that the participants felt free to express themselves. Moreover, the study was conducted during the coronavirus disease (COVID-19) pandemic, and given the restrictions in place, the researcher found it difficult to directly contact the participants for data validation. Data validation was performed through phone calls and chats. The present study has a qualitative design. In order to be able to represent a wider population, a future quantitative study of parent's attitude and behaviour on tobacco smoke should be performed. Future studies should focus on increasing parents' awareness by providing proof of the exposure of children to tobacco smoke, e.g., by measuring the biomarker levels in children. 


\section{Conclusions}

The perceptions of parents of under-5-year-old children with pneumonia about the effects of tobacco smoke were explored in the present study through the obtained themes. Most participants viewed tobacco smoke as being harmful to the health of under-5year-old children and thought that it would lead to children's hospitalization. The participants also mentioned various effects of tobacco smoke and smoking behaviour on the children's health and on the health and well-being of the family. Parents' awareness about the effects of tobacco smoke can serve as the foundation for interventions to protect children from being exposed to tobacco smoke. The implication of this study toward pediatric nursing is that this study highlighted the importance of nurses' role to facilitate, communicate with and educate parents through the consideration of the family's needs, conditions, and cultural background.

Correspondence: Nani Nurhaeni, Department of Pediatric Nursing, Faculty of Nursing, Universitas Indonesia, Jalan Prof. Dr. Bahder Djohan, UI Depok Campus, Depok, West Java 16424, Indonesia. Tel. +62.21.78849120 - Fax: +62.21.7864124.

E-mail: nani-n@ui.ac.id

Key words: Perceptions of parents; phenomenology study; pneumonia; tobacco smoke; under-5-year-old children.

Contributions: All the authors conceived the idea and planned the research, discussed the results and reviewed the final manuscript.

Conflict of interest: Authors declare no conflict of interest.

Acknowledgments: The present study is funded by PUTI Grant from the Direktorat Riset dan Pengembangan, Universitas Indonesia.

Institutions where the research was carried out: $\mathrm{dr}$. Ben Mboi Ruteng Hospital, Manggarai Regency, East Nusa Tenggara, Indonesia

Funding: This study is funded by the Direktorat Riset dan Pengembangan, Universitas Indonesia under HIBAH PUTI SAINTEKES scheme (No: NKB-4627/UN2.RST/HKP.05.00/2020).

Ethical Approval: This study received ethical review and approval from Research Ethic Committee, Faculty of Nursing, Universitas Indonesia (No: SK-10/UN.2.F12.D1.2.1/ETIK.FIK.2020).

Availability of data and materials: The data that support the findings of this study are available from the corresponding author upon reasonable request.

Conference presentation: This final manuscript has been presented at $7^{\text {th }}$ Virtual Biennial International Nursing Conference, Faculty of Nursing, Universitas Indonesia on September $24^{\text {th }}$, October $30^{\text {th }}$, November $16^{\text {th }} 2020$.

Received for publication: 14 August 2020

Accepted for publication: 23 April 2021.

C Copyright: the Author(s), 2021

Licensee PAGEPress, Italy

Journal of Public Health Research 2021; 10(s1):2409

doi:10.4081/jphr.2021.2409

This work is licensed under a Creative Commons Attribution NonCommercial 4.0 License (CC BY-NC 4.0).

\section{References}

1. Watkins K, Wright S, Le Nestour A, et al. Fighting for breath: a call to action on childhood pneumonia. London: Save the Children; 2017. Available from: https://resourcecentre. savethechildren.net/library/fighting-breath-call-action-childhood-pneumonia

2. World Health Organization. Pneumonia. World Health Organization. 2019. Available from: https://www.who.int/ news-room/fact-sheets/detail/pneumonia

3. Ministry of Health of the Republic of Indonesia. [Hasil utama riset kesehatan dasar 2018 (Main results of basic health research 2018)].[in Indonesian]. Jakarta: Ministry of Health of the Republic of Indonesia; 2018. Available from: https://kesmas.kemkes.go.id/assets/upload/dir_519d41d8cd98 f00/files/Hasil-riskesdas-2018_1274.pdf

4. Ministry of Health of the Republic of Indonesia. Data dan informasi: profil kesehatan Indonesia 2018 (Data and information: Indonesia's health profile 2018)].[in Indonesian]. Jakarta: Ministry of Health of the Republic of Indonesia; 2019. Available from: https://pusdatin.kemkes.go.id/resources/ download/pusdatin/profil-kesehatan-indonesia/Data-danInformasi_Profil-Kesehatan-Indonesia-2018.pdf

5. Ministry of Health of the Republic of Indonesia. [Pedoman penyelenggaraan manajemen terpadu balita sakit berbasis masyarakat (MTBS-M) (Guidelines for implementing community-based integrated management of under-five sick children (MTBS-M)].[in Indonesian]. Jakarta: Ministry of Health of the Republic of Indonesia; 2014.

6. Shibata T, Wilson JL, Watson LM, et al. Childhood acute respiratory infections and household environment in an Eastern Indonesian urban setting. Int $\mathrm{J}$ Environ Res Public Health 2014;11:12190-203.

7. de Carvalho Ribeiro FA, de Moraes MKR, de Morais Caixeta $\mathrm{JC}$, et al. Perception of parents about second hand smoke on the health of their children: an ethnographic study. Rev Paul Pediatr 2015;33:394-9.

8. Wipfli H, Avila-Tang E, Navas-Acien A, et al. Secondhand smoke exposure among women and children: evidence from 31 countries. Am J Public Health 2008;98:672-9.

9. Surya E. [Makna simbolik dan fungsi tarian caci di Kabupaten Manggarai Nusa Tenggara Timur (The symbolic meaning and function of the caci dance in Manggarai Regency, East Nusa Tenggara)].[Thesis in Indonesian]. Yogyakarta: Universitas Sanata Dharma; 2009.

10. Firdaus F. Puar cama untuk anak cucu: kearifan lokal untuk sustainability forest di Manggarai Barat (Puar cama for posterity: local wisdom for sustainability forest in West Manggarai)].[Article in Indonesian]. Jurnal Ilmu Sosial Mamangan 2015;1:39-50.

11. Lon YS, Widyawati F. Cultural aspects on child's development and parenting in Manggarai, East Nusa Tenggara, Indonesia. GUIDENA: Jurnal Ilmu Pendidikan, Psikologi, Bimbingan dan Konseling 2017;7:130-9.

12. Rosen L, Kostjukovsky I. Parental risk perceptions of child exposure to tobacco smoke. BMC Public Health 2015;15:90.

13. Myers V, Shiloh S, Rosen L. Parental perceptions of children's exposure to tobacco smoke: development and validation of a new measure. BMC Public Health 2018;18:1031.

14. Halterman JS, Borrelli B, Conn KM, et al. Motivation to quit smoking among parents of urban children with asthma. Patient Educ Couns 2010;79:152-5.

15. Sundler AJ, Lindberg E, Nilsson C, Palmér L. Qualitative the- 
matic analysis based on descriptive phenomenology. Nurs Open 2019;6:733-9.

16. Chen YT, Hsiao FH, Miao NF, Chen PL. Factors associated with parents' perceptions of parental smoking in the presence of children and its consequences on children. Int J Environ Res Public Health 2013;10:192-209.

17. Poornima KS, Reddy PP, Anjum MS, et al. Parental perceptions towards passive smoking: a cross-sectional survey in Vikarabad town, India. Sri Lanka J Child Health 2016;45:2431.

18. Orton S, Jones LL, Cooper S, et al. Predictors of children's secondhand smoke exposure at home: a systematic review and narrative synthesis of the evidence. PLoS One 2014;9:e112690.

19. Hargiana G, Keliat BA, Mustikasari M. The effects of cognitive behavioral therapy on heads of families' smoking behavior and anxiety. Jurnal Keperawatan Indonesia 2018;21:117-26.

20. Myers V, Shiloh S, Zucker DM, Rosen LJ. Changing exposure perceptions: a randomized controlled trial of an intervention with smoking parents. Int $\mathrm{J}$ Environ Res Public Health 2020;17:3349.

21. Zhuge Y, Qian H, Zheng X, et al. Effects of parental smoking and indoor tobacco smoke exposure on respiratory outcomes in children. Sci Rep 2020;10:4311.

22. Groner JA, Huang H, Joshi MS, et al. Secondhand smoke exposure and preclinical markers of cardiovascular risk in toddlers. J Pediatr 2017;189:155-61.
23. Wang X, Wang MP, Viswanath K, et al. Smoking and secondhand smoke exposure at home were associated with poor perceived family well-being: findings of FAMILY project. PLoS One 2016;11:e0161761.

24. Iloh GUP, Collins PI. Awareness of health effects of exposure to secondhand smoke from cigarettes: a cross-sectional study of never-smoked adult primary care patients in Eastern Nigeria. Avicenna J Med 2017;7:164-70.

25. Vanker A, Barnett W, Workman L, et al. Early-life exposure to indoor air pollution or tobacco smoke and lower respiratory tract illness and wheezing in African infants: a longitudinal birth cohort study. Lancet Planet Health 2017;1:e328-36.

26. Homa DM, Neff LJ, King BA, et al. Vital signs: disparities in nonsmokers' exposure to secondhand smoke - United States, 1999-2012. MMWR Morb Mortal Wkly Rep 2015;64:103-8.

27. Toukan AM. The economic impact of cigarette smoking on the poor in Jordan. Value Health Reg Issues 2016;10:61-6.

28. Letuna S. Torok: puisi ritual orang Manggarai - kajian terhadap ritus, makna dan fungsi (Torok: ritual poetry of the Manggarai people - a study of rites, meanings and functions)].[Thesis in Indonesian]. Yogyakarta: Universitas Sanata Dharma; 2015.

29. Saito J, Shibanuma A, Yasuoka J, et al. Education and indoor smoking among parents who smoke: the mediating role of perceived social norms of smoking. BMC Public Health 2018;18:211. 